\title{
Biochar : A Review of its History, Characteristics, Factors that Influence its Yield, Methods of Production, Application in Wastewater Treatment and Recent Development
}

\author{
Nur Salsabila Kamarudin ${ }^{1,2}$, Farrah Aini Dahalan ${ }^{12 * \mathbb{D}}$, Masitah Hasan ${ }^{1,2} \mathbb{D}$, Ong Soon An ${ }^{1,2} \mathbb{D}$, Nor \\ Azizah Parmin ${ }^{3(\mathbb{D})}$, Naimah Ibrahim ${ }^{1,2}(\mathbb{D})$, Myzairah Hamdzah ${ }^{4(\mathbb{D})}$, Nor Azimah Mohd Zain ${ }^{6}{ }^{(\mathbb{D})}$, Khalida \\ Muda ${ }^{5}$ (D) , Edza Aria Wikurendra 7 (D) \\ 1 Water Research and Environmental Sustainable Growth (WAREG), Faculty of Civil Engineering Technology, Universiti \\ Malaysia Perlis (UniMAP), Kompleks Pengajian Jejawi 3, 02600 Arau, Perlis, Malaysia \\ 2 Faculty of Civil Engineering Technology, Universiti Malaysia Perlis (UniMAP), Kompleks Pengajian Jejawi 3, 02600 \\ Arau, Perlis, Malaysia \\ 3 Institute of Nano Electronic Engineering, Universiti Malaysia Perlis, 01000 Kangar, Perlis, Malay sia \\ 4 Research Institute for Sustainable Environment (RISE), Universiti Teknologi Malaysia, 81310 Johor Bahru, Johor \\ 5 Department of Water and Environmental Engineering, School of Civil Engineering, Faculty of Engineering, Universiti \\ Teknologi Malaysia, 81310, Johor Bahru, Johor, Malaysia \\ 6 Department of Biosciences, Faculty of Science, Universiti Teknologi Malaysia, 81310, Skudai, Johor, Malaysia \\ 7 Department of Public Health, Universitas Nahdlatul Ulama Surabaya, 60237 Surabaya, Indonesia \\ * Correspondence: farrahaini@unimap.edu.my (F.A.D.);
}

Scopus Author ID 55845177800

Received: 29.09.2021; Revised: 5.11.2021; Accepted: 8.11.2021; Published: 4.12.2021

\begin{abstract}
Biochar can alleviate several issues, and it should also be inexpensive to produce. Most biochars have a high pore structure and diverse functional groups that assist in the adsorption process. Due to the attributed properties of biochar, several studies have demonstrated that biochar is getting more attention for its efficiency in facilitating wastewater treatment. However, to ensure the feasibility of biochar in wastewater treatment, the factors involved in the preparation of biochar that influences its characteristics and adsorption capacity must be understood. This study reviews the history, characteristics, factors that influence its yield, production methods, application, and recent development of biochar in wastewater treatment.
\end{abstract}

Keywords: biochar; wastewater treatment; water security.

(C) 2021 by the authors. This article is an open-access article distributed under the terms and conditions of the Creative Commons Attribution (CC BY) license (https://creativecommons.org/licenses/by/4.0/).

\section{Introduction}

The Industrial Revolution resulted in a significant shift in the socio-economic circumstances of people across the globe. Not only has the pace of life accelerated as a result of scientific and technological advancement, but so has the quality of life [1]. The consequences of this shift and development have now impacted human life at large. Unfortunate results include global warming, soil pollution, water scarcity and pollution, resource depletion, and food shortages [1]. Rapid industrialization and an increase in agrochemical production have caused a significant increase in the levels of organic and inorganic pesticides and heavy metal pollution in the food web, with consequences for the surrounding environment [2]. The disposal of pollutants into the surrounding ecosystems from industrial, commercial, and residential 
sources disrupt nearby ecosystems. The vast majority of soil and water contamination occurs from human and industrial activities [3]. This has stirred up serious public anxiety about environmental pollution and public health concerns [4]. Many technological innovations are being developed to deal with contaminated soil and water. Reducing contaminants' bioavailability is critical to assuring that contaminants will not build up in plants and animals and minimizing their toxic effects [3].

The most commonly used sorbent is activated carbon, an oxygen-treated carbon to enhance microporosity and surface area [5]. The word "activated" is widely applied to charcoal that has been heated to an elevated temperature or chemically; both produce an increase in the surface area [5]. However, biochar is considered a comparatively inexpensive alternative and an effective adsorbent [6]. Activated carbon requires more heat to produce with the additional process. While it has been said that biochar production requires a lower overall energy input than activated carbon, resulting in lower net energy consumption with a low net cost [6]. Biochar is an inexpensive carbonaceous material but shows some promising potential for removing various organic and inorganic contaminants from the environment [7,8]. Biochar can be distinguished from charcoal based on its commercial purpose [9]. Charcoal is an organic matter used for fuel and energy production, whereas biochar can help to manage the environment through carbon sequestration [9].

Biochar is a product that is high in carbon created by heating biomass like wood, dung, or leaves in a tightly sealed container with little or no ventilation [9]. More precisely, biochar can also be described as a porous carbonic solid formed through the thermochemical conversion of organic material into an environment with low oxygen levels, with physicochemical characteristics suitable for safer long-term storage of carbon [10]. As defined by the International Biochar Initiative (IBI), biochar is a solid material that is derived from biomass decomposition in an oxygen-depleted environment [11].

Biochar can alleviate many issues, and it should also be inexpensive to produce [12]. Most biochar is highly porous and has diverse functional groups that assist in metal adsorption [13]. Previous studies have shown that biochar can significantly boost the long-term carbon sequestration of soil [14-16]. As noted above, biochar has demonstrated potential for bioavailability and intervention to mitigate climate change and improve soil fertility while also addressing environmental contaminants [3]. The introduction of biochar into environmental remediation techniques has recently been looked at as a promising subject because it seems to work in many different ways [17].

There are numerous issues involving water pollution across the globe. About $80 \%$ of industrial wastewater worldwide is discharged directly without treatment into the natural environment, according to the United Nations Water Resources Development Agency [18]. These wastewaters contain harmful organic and inorganic pollutants such as pesticides, herbicides, heavy metals, micropollutants, dyes, and other pollutants, which have a negative environmental impact and threaten people's health $[19,20]$. Biochar as a treatment for wastewater has been the subject of some papers published in recent years. However, there are still issues to contend with biochar production from agricultural by-products effectively and how to successfully apply it to a particular environmental contamination circumstance [21]. While numerous studies have been conducted, the results have been inconclusive overall. The studies of some compounds that are still in their early stages and have not received adequate attention are particularly concerning. This paper reviews the history, characteristics, factors 
that influence its yield, and biochar production methods, including the application of biochar in wastewater treatment and its recent development.

\section{History of Biochar}

The usage of biochar stretches back to 2000 years ago, at the very least [22]. In the midnineteenth century, the first recognition of its application in Western agriculture, but biochar's exact utilization may extend even further in time [12]. The earliest origins of biochar are linked to the American Indian communities of the Amazon Basin $[9,19,23]$. The exceptionally fertile soils known as Terra preta, meaning "the black soils of the Indians", were created by an ancient indigenous culture, providing evidence of extensive biochar use [24,25]. In this soil, the amounts of nutrients, i.e., potassium $(\mathrm{K})$, phosphorus $(\mathrm{P})$, and nitrogen $(\mathrm{N})$ elements, were extremely high [26]. Due to the dark, rich soil characteristics, this region continues to be extremely productive despite hundreds of years of leaching caused by heavy tropical rain [22].

On the other hand, biochar should not be mistaken for Terra preta. Terra preta, also known as "Amazonian dark earth" naturally occurs in nature. It can be artificially created by combining low-temperature charcoal with biomass such as compost, manure plant residues, feces, and bones, and many more [27]. Terra preta differs from biochar in terms of composition and terms of carbon structure [28]. It is critical to consider that the discovery of Terra preta's nutritional value sparked an interest in biochar use [29]. Biochar can be found in soils worldwide because of natural occurrences such as forest and grassland fires [30]. Soils known to have very high levels of biochar concentrations, such as the North American Prairies, are among the most productive soils in the world [22].

Biochar has been used for a long time in agriculture throughout Asia in many different regions, especially in Japan and Korea. Scientists discovered from Terra preta research that biochar had a promising future in absorbing carbon dioxide and reducing carbon emissions in the mid-1990s, as part of the process of seeking to effectively reduce atmospheric carbon dioxide emissions and concentrations to cope with climate change today [19]. Following the first meeting of the International Biochar Advocacy Organization, which was held in Australia in 2007, many countries established National Biochar Societies to initiate biochar research and demonstration conferences and, since then, the amount of research being done on biochar has increased progressively [19].

\section{Characteristics of Biochar}

Biochar is primarily composed of carbon compounds. There are also traces of hydrogen, oxygen, ash, nitrogen, and sulfur [31]. The composition and characteristics of biochar are influenced by the type of biomass used, the design of the reactor, and the conditions under which it is produced [32]. The chemical structure, porosity, amounts of inorganic metals present originally in the feedstock [33], and the process conditions [34] are the most prominent parameters influencing the adsorption properties of biochar.

The surface heterogeneity of biochar is similar to activated carbon [34]. However, biochar reportedly outperforms activated carbon in the removal of various contaminants such as pathogenic organisms, organic matter, surfactants, nitrogen $(\mathrm{N})[35,36]$, micropollutants [37,38], heavy metals [39], and other pollutants because of its large surface area, higher carbon content, high cation and anion exchange capacity, and stable structure [40-42]. Biochar has a wide surface area and a pore network that is evenly dispersed with micropores as large as $2 \mathrm{~nm}$, 
mesopores ranging from 2-50 $\mathrm{nm}$, and macrospores as small as 50nm [43]. Due to its large specific surface area, it possesses a specific adsorption effect on heavy metals and organic ammonia nitrogen in the water [19]. In some cases, the surface area of the biochar was discovered to be lower than activated carbon, but the adsorption capacity was higher. This is because the adsorption of water induces swelling within the biochar, expanding the internal surface area and, due to this, the adsorption capacity will increase [34].

Several studies have been conducted to evaluate the adsorption properties of modified biochar and the impact of functional groups on the adsorption process. Many functional groups can react with one another, and some are also capable of forming hydrogen bonds [44]. Hydrogen bonds give them exceptionally strong bond energy, making it difficult to separate them. Among the commonly used modification techniques are microwave treatments, oxidation, reduction, and metal ion loading [45].

Modified biochar typically contains numerous functional groups, such as - $\mathrm{CHO}$ (aldehyde), - $\mathrm{COOH}$ (carboxyl group), -OH (alcohol or phenol). It exhibits remarkable results in the disposal of toxic metals and organic pollutants from the environment [46]. In the course of the adsorption processes, modified biochar works on both physical and chemical adsorption [47]. However, the dominant adsorption mechanisms may differ depending on the type and properties of the adsorbed pollutant. By expanding the volume of pores and the specific surface area of biochar created by the addition of iron oxides, structural benefits can be achieved [48].

\section{Factors Affecting Biochar Yield}

The biochar yields depend on the categories of feedstocks, whether the pyrolysis was conducted at a high or low temperature, and heating rate [49]. Biomass residue has been widely used in the biochar industry due to its economic and food security privileges over other biomass categories [50]. Waste biomass commonly used for biochar production includes animal feces, plant residues, forest waste, food waste, municipal waste solids, and wastewater [51]. In particular, biomass waste pyrolyzation (particularly sewage loops and animal manure) destroys any existing bacteria and lowers the negative consequences on the environment [9]. Feedstocks are classified into two groups: (i) primarily bio-energy and biochar resource biomass, and (ii) waste biomass by-products [50]. For most feedstock types, animal and solid waste can produce a higher yield of biochar than plant matter or biomass [49].

Biochar has different properties reliant on the pyrolysis temperature [32]. Biochar's morphology and surface structure are strongly linked to the pyrolysis temperature [52]. As reported in previous studies, biochar's adsorption capacity is strongly influenced by temperature [34]. Biochar can be produced by pyrolysis at temperatures ranging from 200$900^{\circ} \mathrm{C}$, which occurs in the absence of much lower oxygen levels [53]. Generally, there are two types of pyrolysis: fast and slow pyrolysis [54]. Fast pyrolysis that occurs in a very short period of time (less than 2 seconds) is well known for producing bio-oil from biomass, yielding 75\% of bio-oil [54]. Most biochar is generated through slow pyrolysis processes that take several hours to several days to produce biochar [55].

A previous study found a decrease in the amount of biochar when the heating rate increased [56]. At higher pyrolysis temperatures, the surface area generally increases [57]. In this process, it is believed that the aliphatic alkyl and ester groups are being destroyed, and the exposed aromatic lignin component is contributing to the increase in the surface area [58]. The relationship between micropore volume and surface area is directly proportional, and the increase in surface area is primarily due to the increased pore size distribution of the biochar 
[59]. Biochar produced at higher temperatures is more effective at remedying soil and water contamination due to the increased surface area and the biochar's microporosity [32]. In contrast, biochar produced with a low heating rate has a smaller surface area, owing to deformation, cracking, or micropore blockage $[52,60]$. Thus, biochar ought to be produced under well-defined pyrolysis circumstances in order to produce the highest quality yield possible [32].

\section{Production of Biochar}

Noticeably, the availability of feedstock and its composition are two of the most important variables influencing the economical and efficient production of biochar. For biochar production, a variety of feedstock options are available. These include agricultural biomass, urban waste, paper waste, and aquatic and woody biomass [61]. Agriculture wastes such as rice straw [62], cotton stalk [63], and coconut shell [64] are the most commonly used agricultural wastes in the production of biochar. In terms of municipal waste, papermill sludge [65] and sewage sludge [66] are the most commonly used feedstocks for biochar production. Pine sawdust [67] and waste wood chips [68] are examples of woody biomass, while aquatic biomass such as Macroalgae sp. and seaweed [69] is commonly utilized as feedstock for biochar production.

Traditional biochar production methods include piling it up in soil pits and allowing it to burn slowly with little or no airflow [70]. A different method was to burn the biomass in an open area and immediately cover the half-burned biomass with soil [71]. This process is known as pyrolysis. Pyrolysis is a thermal degradation technique that uses heat to degrade biomass while restricting the presence of oxygen [72]. Slow pyrolysis and fast pyrolysis are methods in traditional approaches [61].

To produce biochar, the selected biomass is dried thoroughly before being pulverized. Then, the pulverized particles were milled down to the next lower limit of 40 mesh size [73]. To achieve slow pyrolysis, biomass must be heated at a temperature in the range of $300-600^{\circ} \mathrm{C}$ at a rate of 5 to $7^{\circ} \mathrm{C}$ per minute for at least $>24$ hours [68]. The slow pyrolysis process is generally performed with a continuous auger/screw pyrolyzer reactor [74]. As a result, biochar is produced as a major product (35-45\%) alongside bio-oil (25-35\%) and syngas (20-30\%) [74]. The operation of fast pyrolysis is carried out at a temperature greater than $500^{\circ} \mathrm{C}$ and a heating rate greater than $300^{\circ} \mathrm{C}$ per minute in the absence of oxygen [75]. Within a few seconds, the yield of fast pyrolysis is reported to be $60 \%$ bio-oil, $20 \%$ biochar, and $20 \%$ syngas [75]. The summary of slow and fast pyrolysis is shown in Table 1 . Fast pyrolysis is primarily used to produce biochar on a large scale.

Table 1. The summary of slow and fast pyrolysis

\begin{tabular}{c|c|c|c|c} 
Method & $\begin{array}{c}\text { Temperature } \\
\left({ }^{\circ} \mathbf{C}\right)\end{array}$ & $\begin{array}{c}\text { Heating rate } \\
\mathbf{m i n}^{-1}\left({ }^{\circ} \mathbf{C}\right)\end{array}$ & $\begin{array}{c}\text { Duration } \\
(\mathbf{s} / \mathbf{h} / \mathbf{m i n} / \mathbf{d a y s})\end{array}$ & Yields $(\%)$ \\
\hline \multirow{2}{*}{ Slow pyrolysis } & $300-600$ & $5-7$ & Min to days & $\begin{array}{c}35-45 \text { biochar } \\
25-35 \text { bio-oil } \\
20-30 \text { syngas }\end{array}$ \\
\hline \multirow{2}{*}{ Fast pyrolysis } & $>500$ & $>300$ & $\sim 55,68,74]$ & 60 bio-oil \\
& & & & 20 biochar \\
syngas
\end{tabular}




\section{Application of Biochar in Wastewater Treatment}

As our demand on the environment continues to grow, many pollutants with low concentrations but significant environmental harm are gradually gaining attention [47]. Sewage from industrial processes released into the environment may cause humans' carcinogenicity, toxicity, mutagenicity, and teratogenicity [76].

While many techniques exist for wastewater treatment, five, in particular, are commonly used: adsorption [34,77], chemical precipitation, membrane separation, constructed wetlands, and ion exchange [78]. However, some of these technologies have a number of drawbacks, including inefficiency in removing pollutants at low concentrations, being unable to convert contaminants into biodegradable or less harmful by-products, excessive use of energy and chemicals, the difficulty of the process, and high costs of operation and maintenance $[79,80]$.

The adsorption method is adaptable and effective, making it the primary treatment method. Due to its massive specific surface area and functional divisions, researchers are paying special attention to biochar in the study of adsorption [81]. The surface properties of biochar can be altered to improve adsorption efficiency. The inexpensive cost of biochar is another major feature contributing to its appeal. Biochar is made primarily from solid waste and agricultural waste, which is one aspect that contributes to its low cost. In other research, the price of modified biochar was found to be nearly half that of activated carbon, and its adsorption capability was shown to be nearly equal [82].

Previous experiments have proven that biochar is effective at removing organic matter, surfactants, and nitrogen $(\mathrm{N})$ from wastewater $[35,36]$. Biochar can be used successfully as a phosphorus (P) sorbent in the wastewater treatment process [83]. Then, the sorbent produced different types of products (phosphorous fertilizers) using the method of recycling, which is widely recognized for having the ability to improve the soil condition [83]. Micropollutants are a type of chemical pollution that can endanger human well-being and the environment. Micropollutants are extremely complicated organic compounds found mostly in water [84]. Pharmaceuticals, antibiotics, cosmetics and toiletries, endocrines, organic contaminants with a long-life cycle, disinfection by-products, and other industrial chemicals are the most common sources of micropollutants [47,84]. Environmentally persistent and long-lasting, these micropollutants can be found in a wide variety of environments. Despite the fact that most micropollutants are present in extremely low amounts in water, they still have the potential to cause detrimental consequences for human health and the environment due to their accumulation by organisms throughout the food chain [85]. One of the micropollutants that can be found in water bodies is antibiotics such as tetracycline, doxycycline, and clindamycin [8688], personal care products such as triclosan [89], analgesics such as ibuprofen and carbamazepine [90], and psychoactive drugs such as caffeine [88]. Research into the utilization of modified biochar to remove tetracycline and other micropollutants from water has been ongoing for quite some time $[37,38]$.

In recent studies, biochar has been shown to be effective in removing inorganic pollutants from wastewater, such as heavy metals [39]. Heavy metals are among the contaminants that can be found in wastewater. It can accumulate in organisms, posing a threat to the quality of life of other food chain members, especially humans [6]. In aqueous solutions, the primary concern of organic contaminants is dyes [39]. Research into biochar produced from bio-oil for the removal of chromium $(\mathrm{Cr})$ has already been done [91]. Hexavalent chromium 
$\mathrm{Cr}(\mathrm{VI})$ compounds are commonly used as dye pigments in the industry [92]. The biochar-based adsorbents have been proven to have a high adsorption capacity for this compound [92]. Biochar has been touted as a good way to remove methyl violet from wastewater, which has been anticipated to be a possible adsorbent [93].

\section{Recent Development}

Although biochar has a large adsorption capacity for numerous contaminants, a detailed understanding of the methods regulating the adsorption process is still lacking [39]. New problems and challenges will inevitably arise due to the advancement of biochar research and development [47]. To stay ahead of modern treatment technology, more methods should be developed to make full use of biochar and remove pollutants from the environment, especially in the application of wastewater. Integration of biochar into current and advanced wastewater treatment systems might be considered and explored.

Biochar modification is an important area that must be discussed further to improve biochar's capacity to remove specific contaminants from the environment. A larger number of studies are required to pinpoint how the modification process may be altered and the various mechanisms involved, which vary depending on the modification agents utilized $[39,94]$. The study of biochar modification is still in its infancy, but the application potential of biochar is enormous. Accelerating the advancement of biochar research technology will aid in the expansion of the scope of biochar's application [19]. Recent advancements in nanotechnology offer a wide array of opportunities to improve water treatment technologies in the future [95]. Combining biochar with other treatment strategies, for example, mixing biochar with a biofilter, can improve biochar's excellent adsorption capability for environmental remediation [96-103].

Biochar has already shown itself to be widely applicable in wastewater treatment applications, but scientists should remain mindful of its possible environmental effects [104-110]. The potential carbon release from biochar during wastewater decontamination may increase the carbon content of the treated water. Because biochar is a biomass pyrolysis product produced at low temperatures $\left(300-800^{\circ} \mathrm{C}\right)$ and without the use of an activation process, it is not completely carbonized. It also includes toxic elements and nanoparticle pollution in biochar-based materials [19]. The discharge of heavy metals from biochar derived from sludge is a possibility, particularly for biochar derived from sludge [39]. Thus, more research should be done to find ways to maximize the process of making biochar and reduce pollution [19].

\section{Conclusions}

Biochar is a useful material and has a high potential to substitute activated carbon. It is an effective and cheaper adsorbent that can be created from a wide range of biomass materials, including agricultural waste, sewage sludge, crop residues, manures, forestry residues, and other solid waste. As discussed, biochar could be utilized as an amendment for soil improvement, a sorbent to eliminate contamination from soil and water, reduce the emission of various greenhouse gases and store carbon dioxide or hydrogen. The growing number of pollutants with low concentrations but significant environmental harm is gradually gaining attention as human demands on the environment continue to grow. Wastewater from industrial processes that are released into the environment has the potential to cause detrimental effects on the environment and also on humans. Even though there are many different wastewater 
treatment techniques available, the adsorption method is the most adaptable and effective, making it the primary treatment method. Due to its wide range of surface area and functional divisions, biochar is receiving particular attention in the study of adsorption in wastewater. Looking at things from a sustainable perspective, biochar may have a bright future in the long term. To enhance the physiochemical and adsorption qualities of biochar, surface modification techniques can be employed. The research into biochar modification, on the other hand, is still in its infancy, even though biochar has immense application potential. It will take a larger number of studies to identify all of the different ways in which the modification process can be manipulated. A wide range of opportunities for the development of water treatment technologies has opened up as a result of recent advances in nanotechnology.

\section{Funding}

This research was funded by the Ministry of Higher Education Malaysia FRGS/1/2020/TK0/UNIMAP/02/104 and collaboratively supported by UTM - CRG16.

\section{Acknowledgments}

The authors acknowledge UniMAP and UTM for supporting this research.

\section{Conflicts of Interest}

The authors declare no conflict of interest.

\section{References}

1. Kumar, A.; Bhattacharya, T. Biochar: a sustainable solution. Environ Dev Sustain 2020, 23, 6642-6680, https://doi.org/10.1007/s10668-020-00970-0.

2. World Health Organization, (2017). Available online: https://www.who.int/publications/i/item/WHO-FWCIHE-17.01 (accessed on 10 February 2020).

3. Sohi, S.P. Carbon storage with benefits. Science 2012, 338, 1034-1035, https://doi.org/10.1126/science.1225987.

4. Spokas, K.A.; Koskinen, W.C.; Baker, J.M.; Reicosky, D.C. Impacts of woodchip biochar additions on greenhouse gas production and sorption/degradation of two herbicides in a Minnesota soil. Chemosphere 2009, 77, 574-581, https://doi.org/10.1016/j.chemosphere.2009.06.053.

5. Cao, X.; Ma, L.; Liang, Y.; Gao, B.; Harris, W. Simultaneous immobilization of lead and atrazine in contaminated soils using dairy-manure biochar. Environ Sci Technol 2011, 45, 4884-4889, https://doi.org/10.1021/es103752u.

6. Tan, Z.; Lin, C.; Ji, X.; Rainey, T. Returning biochar to fields: A review. Appl Soil Ecol 2017, 116, 1-11, http://dx.doi.org/10.1016/j.apsoil.2017.03.017.

7. Lu, K.; Yang, X.; Shen, J.; Robinson, B.; Huang, H.; Liu, D.; Bolan, N.; Pei, J.; Wang, H. Effect of bamboo and rice straw biochars on the bioavailability of $\mathrm{Cd}, \mathrm{Cu}, \mathrm{Pb}$ and $\mathrm{Zn}$ to Sedum plumbizincicola. Agr Ecosys Environ 2014, 191, 124-132, http://dx.doi.org/10.1016\%2Fj.agee.2014.04.010.

8. Xu, T.; Lou, L.; Luo, L.; Cao, R.; Duan, D.; Chen, Y. Effect of bamboo biochar on pentachlorophenol leachability and bioavailability in agricultural soil. Sci Total Environ 2012, 414, 727-731, https://doi.org/10.1016/j.scitotenv.2011.11.005.

9. Lehmann, J.; Joseph, S. Biochar for environmental management: an introduction. In: Biochar for Environmental Management Science and Technology. First edition.; Lehmann, J.; Joseph, S. Eds.; Earthscan: London, UK, Volume 1, 2009; pp. 1-9, https://doi.org/10.4324/9781849770552.

10. Shackley, S.; Carter, S.; Knowles, T.; Middelink, E.; Haefele, S.; Sohi, S.; Cross, A.; Haszeldine, S. Sustainable gasification-biochar systems? A case-study of rice-husk gasification in Cambodia, Part I: Context, chemical properties, environmental and health and safety issues. Energy Policy 2012, 42, 49-58, https://doi.org/10.1016/j.enpol.2011.11.026.

11. International Biochar Initiative (IBI). Available online: https://biocharinternational.org/characterizationstandard/ (accessed on 20 October 2020).

12. Abiven, S.; Schimdt, M.W.I.; Lehmann, J. Biochar by Design. Nat Geosci 2014, 7, 326-327, https://doi.org/10.1038/ngeo2154. 
13. Wu, W.; Yang, M.; Feng, Q.; McGrouther, K.; Wang, H.; Lu, H.; Chen, Y. Chemical characterization of rice straw-derived biochar for soil amendment. Biomass and Bioenergy 2012, 47, 268-276, https://doi.org/10.1016/j.biombioe.2012.09.034.

14. Jeffery, S.; Verheijen, F.; Velde, M.; Bastos, A. A quantitative review of the effects of biochar application to soils on crop productivity using meta-analysis. Agric Ecosyst Environ 2011, 144, 175-187, https://doi.org/10.1016/j.agee.2011.08.015.

15. Kookana, R.S.; Sarmah, A.K.; Van-Zwieten, L.; Krull, E.; Singh, B. Chapter three- biochar application to soil: agronomic and environmental benefits and unintended consequences. In: Advances in Agronomy. Donald, L.S. Eds.; Elsevier: Amsterdam, Netherlands, Volume 112, 2011; pp. 103-143, http://dx.doi.org/10.1016/B978-0-12-385538-1.00003-2.

16. Lehmann, J. A handful of carbon. Nature 2007, 447, 143-144, https://doi.org/10.1038/447143a.

17. Awad, Y.M.; Blagodatskaya, E.; Ok, Y.S.; Kuzyakov, Y. Effects of polyacrylamide, biopolymer, and biochar on decomposition of soil organic matter and plant residues as determined by $14 \mathrm{C}$ and enzyme activities. Eur J Soil Biol 2012, 48, 1-10, http://dx.doi.org/10.1016/j.ejsobi.2011.09.005.

18. Water Quality and Wastewater. Available online: https://www.unwater.org/water-facts/quality-andwastewater/ (accessed on 20 October 2020).

19. Han, C.; Chen, F.; Lian, C.; Liang, R.; Liang, W.; Chen, M.; Luo, A.; Gao, T. Development of preparation method and application of biochar. Int $J$ Emerg Technol Adv Eng 2020, 10, 6-13, http://dx.doi.org/10.46338/IJETAE0920_02.

20. Kumi, A.G; Ibrahim, M.G; Nasr, M.; Fujii, M. Biochar synthesis for industrial wastewater treatment: a critical review. Mater Sci Forum 2020, 1008, 202-212, https://doi.org/10.4028/www.scientific.net/MSF.1008.202.

21. Lap, B.Q.; Thinh, N.V.D.; Hung, N.T.Q.; Nam, N.H.; Dang, H.T.T.; Ba, H.T.; Ky, N.M.; Tuan, H.N.A. Assessment of Rice Straw-Derived Biochar for Livestock Wastewater Treatment. Water, Air, \& Soil Pollution 2021, 232, https://dx.doi.org/10.1007/s11270-021-05100-8.

22. Hunt, J.; DuPonte, M.; Sato, D.; Kawabata, A. The basics of biochar : a natural soil amendment. Soil and Crop Manag 2010, 1-6.

23. Lehmann, J. Terra preta Nova - where to from here?. In: Amazonian Dark Earths: Wim Sombroek's Vision. Woods, W.I.; Teixeira, W.G.; Lehmann, J.; Steiner, C.; WinklerPrins, A.M.G.A.; Rebellato, L.Eds.; Springer: Dordrecht, Netherlands, Volume 28, 2009; pp. 473-486, https://doi.org/10.1007/978-1-4020-9031-8_28.

24. O’Neill, B.; Grossman, J.; Tsai, M.T.; Gomes, J.E.; Lehmann, J.; Peterson, J.; Neves, E.; Thies, J.E. Bacterial community composition in Brazilian Anthrosols and adjacent soils characterized using culturing and molecular identification. Microb Ecol 2009, 58, 23-35, https://doi.org/10.1007/s00248-009-9515-y.

25. Tenenbaum, D. Biochar: carbon mitigation from the ground up. Environ Health Perspec 2009, 117, 70-73, https://dx.doi.org/10.1289\%2Fehp.117-a70.

26. Chen, W.; Meng, J.; Han, X.; Lan, Y.; Zhang, W. Past, present, and future of biochar. Biochar 2019, 1, 7587, https://doi.org/10.1007/s42773-019-00008-3.

27. Graham, E. A neotropical framework for Terra Preta. In: Time and complexity in historical ecology: Studies in the Neotropical Lowlands. Balee, W.; Erickson, C.L. Eds.; Columbia University Press: New York, USA, Volume 2, 2006; pp. 57-86, https://doi.org/10.7312/bale13562-005.

28. Igalavithana, A.D.; Mandal, S.; Niazi, N.K.; Vithanage, M.; Parikh, S.J.; Mukome, F.N.D.; Rizwan, M.; Oleszczuk, P.; Al-Wabel, M.; Bolan, N.; Tsang, D.C.W.; Kim, K.-H.; Ok, Y.S. Advances and future directions of biochar characterization methods and applications. Crit Rev Environ Sci Technol 2018, 47, 2275-2330, https://doi.org/10.1080/10643389.2017.1421844.

29. Glaser, B.; Lehmann, J.; Zech, W. Ameliorating physical and chemical properties of highly weathered soils in the tropics with charcoal - a review. Biol Fertil Soils 2002, 35, 219-230, https://doi.org/10.1007/s00374002-0466-4.

30. Krull, E.S.; Baldock, J.A.; Skjemstad, J.O.; Smernik, R.J. Characteristics of biochar: organo-chemical properties. In: Biochar for environmental management: Science and technology. Lehmann, J.; Joseph, S. Eds.; Earthscan: London, UK, Volume 4, 2009; pp. 53-63, http://dx.doi.org/10.4324/9781849770552.

31. Ahmad, J.; Cordioli, E.; Patuzzi, F.; Prando, D.; Castaldi, M.; Baratieri, M. Possible utilization pathways of char from biomass thermochemical conversion: char as a catalytic filtering medium for tar cracking. 24th Eur Biomass Conf Exhib 2016, 475-479, http://dx.doi.org/10.5071/24thEUBCE2016-2BO.2.3.

32. Ahmad, M.; Rajapaksha, A.U.; Lim, J.E.; Zhang, M.; Bolan, N.; Mohan, D.; Vithanage, M.; Lee, S.S.; Ok, Y.S. Biochar as a sorbent for contaminant management in soil and water: A review. Chemosphere 2014, 99, 19-33, https://doi.org/10.1016/j.chemosphere.2013.10.071.

33. Kong, L.; Xiong, Y.; Sun, L.; Tian, S.; Xu, X.; Zhao, C.; Luo, R.; Yang, X.; Shih, K.; Liu, H. Sorption performance and mechanism of a sludge-derived char as porous carbon-based hybrid adsorbent for benzene derivatives in aqueous solution. $J$ Hazard Mater 2014, 274, 205-211, https://doi.org/10.1016/j.jhazmat.2014.04.014.

34. Ahmad, J.; Patuzzi, F.; Rashid, U.; Shahabz, M.; Ngamcharussrivichai, C.; Baratieri, M. Exploring untapped effect of process conditions on biochar characteristics and applications. Environ Technol Innov 2020, 21, https://doi.org/10.1016/j.eti.2020.101310. 
35. Dalahmeh, S. Capacity of biochar filters for wastewater treatment in onsite systems - Technical report: report 2016-90. Swedish University of Agricultural Sciences 2016, 1-43.

36. Berger, C. Biochar and activated carbon filters for greywater treatment: comparison of organic matter and nutrient removal. In: Energy and Technology. Swedish University of Agricultural Sciences, Uppsala, Sweden, 2012.

37. Nguyen, V.-T.; Hung, C.-M.; Nguyen, T.-B.; Chang, J.-H.; Wang, T.-H.; Wu, C.-H.; Lin, Y.-L.; Chen, C.W.; Dong, C.-D. Efficient Heterogeneous Activation of Persulfate by Iron-Modified Biochar for Removal of Antibiotic from Aqueous Solution: A Case Study of Tetracycline Removal. Catalysts 2019, 9, https://doi.org/10.3390/catal9010049.

38. Zhou, Y.; He, Y.; He, Y.; Liu, X.; Xu, B.; Yu, J.; Dai, C.; Huang, A.; Pang, Y.; Luo, L. Analyses of tetracycline adsorption on alkali-acid modified magnetic biochar: Site energy distribution consideration. Science of The Total Environment 2019, 650, 2260-2266, https://doi.org/10.1016/j.scitotenv.2018.09.393.

39. Enaime, G.; Baçaoui, A.; Yaacoubi, A.; Lübken, M. Biochar for wastewater treatment-conversion technologies and applications. Appl Sci 2020, 10, https://doi.org/10.3390/app10103492.

40. Kaetzl, K.; Lübken, M.; Gehring, T.; Wichern, M. Effcient low-cost anaerobic treatment of wastewater using biochar and woodchip filters. Water 2018, 10, https://doi.org/10.3390/w10070818.

41. Rizwan, M.; Ali, S.; Qayyum, M.F.; Ibrahim, M.; Zia-ur-Rehman, M.; Abbas, T.; Ok, Y.S. Mechanisms of biochar-mediated alleviation of toxicity of trace elements in plants: A critical review. Environ Sci Pollut Res 2015, 23, 2230-2248, https://doi.org/10.1007/s11356-015-5697-7.

42. Reddy, K.R.; Xie, T.; Dastgheibi, S. Evaluation of biochar as a potential filter media for the removal of mixed contaminants from urban storm water runoff. $J$ Environ Eng 2014, 140, http://dx.doi.org/10.1061/(ASCE)EE.1943-7870.0000872.

43. Mukherjee, A.; Zimmerman, A.R.; Harris, W. Surface chemistry variations among a series of laboratoryproduced biochars. Geoderma 2011, 163, 247-255, https://doi.org/10.1016/j.geoderma.2011.04.021.

44. Vijay, D.; Zipse, H.; Sastry, G.N. On the cooperativity of cation-pi and hydrogen bonding interactions. J Phys Chem B 2008, 112, 8863-8867, https://doi.org/10.1021/jp804219e.

45. Yang, X.; Zhang, S.; Ju, M.; Liu, L. Preparation and modification of biochar materials and their application in soil remediation. Appl Sci 2019, 9, 1365, https://doi.org/10.3390/app9071365.

46. Wu, J.; Lu, J.; Zhang, C.; Zhang, Z.H.; Min, X.Y. Adsorptive removal of tetracyclines and fluoroquinolones using yak dung biochar. Bull Environ Contam Toxicol 2019, 102, 407-412, https://doi.org/10.1007/s00128018-2516-0.

47. Cheng, N.; Wang, B.; Wu, P.; Lee, X.; Xing, Y.; Chen, M.; Gao, B. Adsorption of emerging contaminants from water and wastewater by modified biochar: A review. Environ Pollut 2021, 273, https://doi.org/10.1016/j.envpol.2021.116448.

48. Ren, J.; Li, N.; Li, L.; An, J.K.; Zhao, L.; Ren, N.Q. Granulation and ferric oxides loading enable biochar derived from cotton stalk to remove phosphate from water. Bioresour Technol 2015, 178, 119-125, https://doi.org/10.1016/j.biortech.2014.09.071.

49. Enders, A.; Hanley, K.; Whitman, T.; Joseph, S.; Lehmann, J. Characterization of biochars to evaluate recalcitrance and agronomic performance. Bioresour Technol 2012, 114, 644-653, https://doi.org/10.1016/j.biortech.2012.03.022.

50. Brick, S. Biochar: assessing the promise and risks to guide US Policy. Natural Resource Defense Council 2010, 1-18.

51. Cantrell, K.B.; Hunt, P.G.; Uchimiya, M.; Novak, J.M.; Ro, K.S. Impact of pyrolysis temperature and manure source on physicochemical characteristics of biochar. Bioresour Technol 2012, 107, 419-428, https://doi.org/10.1016/j.biortech.2011.11.084.

52. Liu, Z.; Zhang, F.S.; Wu, J. Characterization and application of chars produced from pinewood pyrolysis and hydrothermal treatment. Fuel 2010, 89, 510-514, https://doi.org/10.1016/j.fuel.2009.08.042.

53. Demirbas, A.; Arin, G. An overview of biomass pyrolysis. Energy Source 2002, 24, 471-482, https://doi.org/10.1080/00908310252889979.

54. Mohan, D.; Pittman, C.U.; Steele, P.H. Pyrolysis of wood/biomass for bio-oil: a critical review. Energy Fuels 2006, 20, 848-889, https://doi.org/10.1021/ef0502397.

55. Brown, R., Biochar Production Technology. In: Biochar for Environmental Management: Science and Technology. First Edition; Lehmann, J.; Joseph, S. Eds,; Earthscan: London, UK, 2009; pp. 127-139, https://doi.org/10.4324/9781849770552.

56. Karaosmanog lu, F.; Işı̄̄ı̈̈ür-Ergüdenler, A.; Sever, A. Biochar from the straw-stalk of rapeseed plant. Energy Fuels 2000, 14, 336-339, https://doi.org/10.1021/ef9901138.

57. Uchimiya, M.; Klasson, K.T.; Wartelle, L.H.; Lima, I.M. Influence of soil properties on heavy metal sequestration by biochar amendment: 1 . Copper sorption isotherms and the release of cations. Chemosphere 2011, 82, 1431-1437, https://doi.org/10.1016/j.chemosphere.2010.11.050.

58. Chen, B.; Chen, Z. Sorption of naphthalene and 1-naphthol by biochars of orange peels with different

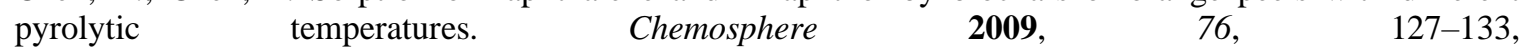
https://doi.org/10.1016/j.chemosphere.2009.02.004. 
59. Downie, A., Crosky, A., and Munroe, P. Physical properties of biochar. In: Biochar for environmental management: Science and technology. First edition.; Lehmann, J.; Joseph, S. Eds.; Earthscan: London, UK, Volume 2, 2009; pp. 13-30, http://dx.doi.org/10.4324/9781849770552.

60. Lian, F.; Huang, F.; Chen, W.; Xing, B.; Zhu, L. Sorption of apolar and polar organic contaminants by waste tire rubber and its chars in single- and bi-solute systems. Environ Pollut 2011, 159, 850-857, https://doi.org/10.1016/j.envpol.2011.01.002.

61. Gabhane, J.W.; Bhange, V.P.; Patil, P.D.; Bankar, S.T.; Kumar, S. Recent trends in biochar production methods and its application as a soil health conditioner: a review. SN Applied Sciences 2020, 2, https://doi.org/10.1007/s42452-020-3121-5.

62. Jeong, C.Y.; Dodla, S.K.; Wang, J.J. Fundamental and molecular composition characteristics of biochars produced from sugarcane and rice crop residues and by-products. Chemosphere 2016, 142, 4-13, https://doi.org/10.1016/j.chemosphere.2015.05.084.

63. Shen, B.; Chen, J.; Yue, S.; Li, G. A comparative study of modified cotton biochar and activated carbon based catalysts in low temperature SCR. Fuel 2015, 156, 47-53, http://dx.doi.org/10.1016/j.fuel.2015.04.027.

64. Jegajeevagan, K.; Mabilde, L.; Gebremikael, M.T.; Ameloot, N.; De Neve, S.; Leinweber, P.; Sleutel, S. Artisanal and controlled pyrolysis-based biochars differ in biochemical composition, thermal recalcitrance, and biodegradability in soil. Biomass Bioenerg 2016, 84, 1-11, http://dx.doi.org/10.1016/j.biombioe.2015.10.025.

65. Van Zwieten, L.; Kimber, S.; Morris, S.; Chan, K.Y.; Downie, A.; Rust, J.; Joseph, S.; Cowie, A. Effects of biochar from slow pyrolysis of papermill waste on agronomic performance and soil fertility. Plant Soil 2010, 327, 235-246, https://doi.org/10.1007/s11104-009-0050-x.

66. Yuan, H.; Lu, T.; Wang, Y.; Chen, Y.; Lei, T. Sewage sludge biochar: nutrient composition and its effect on the leaching of soil nutrients. Geoderma 2016, 267, 17-23, https://doi.org/10.1016/j.geoderma.2015.12.020.

67. Srinivasan, P.; Sarmah, A.K.; Smernik, R.; Das, O.; Farid, M.; Gao, W. A feasibility study of agricultural and sewage biomass as biochar, bioenergy and biocomposite feedstock: production, characterization and potential applications. Sci Total Environ 2015, 512, 495-505, https://doi.org/10.1016/j.scitotenv.2015.01.068.

68. Lai, W.-Y.; Lai, C.-M.; Ke, G.-R.; Chung, R.-S.; Chen, C.-T.; Cheng, C.-H.; Pai, C.-W.; Chen, S.-Y.; Chen, C.-C. The effects of woodchip biochar application on crop yield, carbon sequestration and greenhouse gas emissions from soils planted with rice or leaf beet. J Taiwan Inst Chem Eng 2013, 44, 1039-1044, https://doi.org/10.1016/j.jtice.2013.06.028.

69. Roberts, D.A.; Cole, A.J.; Paul, N.A.; de-Nys, R. Algal biochar enhances the re-vegetation of stockpiled mine soils with native grass. J Environ Manage 2015, 161, 173-180, https://doi.org/10.1016/j.jenvman.2015.07.002.

70. Barrow, C.J. Biochar: potential for countering land degradation and for improving agriculture. Appl Geogr 2012, 34, 21-28, https://doi.org/10.1016/j.apgeog.2011.09.008.

71. Emrich, W. Traditional methods of the smallholder charcoal-maker. In: Handbook of Charcoal Making. Emrich, W. Eds.; Springer, Dordrecht, Netherlands, Volume 7, 2013; pp. 19-104, https://doi.org/10.1007/978-94-017-0450-2_2.

72. Basu, P. Pyrolysis and Torrefaction. In: Biomass gasification and pyrolysis: practical design and theory. Academic Press: Burlington, USA, 2010; pp. 65-96.

73. Rambli, J.; Ghani, W.A.WA.K.; Salleh, M.A.M. Characterization of sago-based biochar feedstock for solid fuel. Journal of Energy and Safety Technology 2018, 1, 11-17, http://dx.doi.org/10.11113/jest.v1n2.16.

74. Verma, M.; Godbout, S.; Brar, S.K.; Solomatnikova, O.; Lemay, S.P.; Larouche, J.P. Biofuels production from biomass by thermochemical conversion technologies. Int $J$ Chem Eng 2012, 1-18, https://doi.org/10.1155/2012/542426.

75. Dai, L.; Fan, L.; Liu, Y.; Ruan, R.; Wang, Y.; Zhou, Y.; Zhao, Y.; Yu, Z. Production of bio-oil and biochar from soapstock via microwave- assisted co-catalytic fast pyrolysis. Bioresour Technol 2017, 225, 1-8, https://doi.org/10.1016/j.biortech.2016.11.017.

76. Goltz, M.N.; Gandhi, R.K.; Gorelick, S.M.; Hopkins, G.D.; Smith, L.H.; Timmins, B.H.; McCarty, P.L. Field evaluation of in situ source reduction of trichloroethylene in groundwater using bioenhanced in-well vapor stripping. Environ Sci Technol 2005, 39, 8963-8970, https://doi.org/10.1021/es050628f.

77. Catizzone, E.; Sposato, C.; Romanelli, A.; Barisano, D.; Cornacchia, G.; Marsico, L.; Cozza, D.; Migliori, M.Purification of wastewater from biomass-derived syngas scrubber using biochar and activated carbons. Int J Environ Res Public Health 2021, 18, 4247, https://doi.org/10.3390/ijerph18084247.

78. Li, F.; Duan, F.; Ji, W.; Gui, X. Biochar-activated persulfate for organic contaminants removal: Efficiency, mechanisms and influencing factors. Ecotoxicol Environ Saf 2020, 198, https://doi.org/10.1016/j.ecoenv.2020.110653.

79. Cheng, Z.; Fu, F.; Dionysiou, D.D.; Tang, B. Adsorption, oxidation, and reduction behavior of arsenic in the removal of aqueous As(III) by mesoporous Fe/Al bimetallic particles. Water Res 2016, 96, 22-31, https://doi.org/10.1016/j.watres.2016.03.020.

80. Fu, F.; Wang, Q. Removal of heavy metal ions from wastewaters: a review. J Environ Manage 2011, 92 , 407-418, https://doi.org/10.1016/j.jenvman.2010.11.011. 
81. Bu, J.B.; Wenyu, L.; Ning, N.; Ning, G.; Hao, Z.; Cheng, C.; Ding, A. Adsorption of Cr(VI) from wastewater by iron-modified coconut shell biochar. E3S Web Conf 2021, 248, 1-4, https://doi.org/10.1051/e3sconf/202124801059.

82. Fdez-Sanroman, A.; Pazos, M.; Rosales, E.; Sanroman, M.A. Unravelling the environmental application of biochar as low-cost biosorbent: a review. Appl Sci 2020, 10, https://doi.org/10.3390/app10217810.

83. Kopecký, M.; Koláŕ, L.; Konvalina, P.; Strunecký, O.; Teodorescu, F.; Mráz, P.; Peterka, J.; Váchalová, R.; Bernas, J.; Bartoš, P.; Filipov, F.; Bucur, D. Modified biochar-a tool for wastewater treatment. Energies 2020, 13, https://doi.org/10.3390/en13205270.

84. Bo, L.; Zhang, S.G.; Chang, C.C.; Dong, Z.F.; Li, H.X. Emerging pollutants - Part II: treatment. Water Environ. Res 2015, 87, 1873-1900.

85. Gomes, A.R.; Justino, C.; Rocha-Santos, T.; Freitas, A.C.; Duarte, A.C.; Pereira, R. Review of the ecotoxicological effects of emerging contaminants to soil biota. J Environ Sci Health - Part A Toxic/Hazard Subst Environ Eng 2017, 52, 992-1007, https://doi.org/10.1080/10934529.2017.1328946.

86. Liu, R.; Li, S.; Tu, Y.; Hao, X. Capabilities and mechanisms of microalgae on removing micropollutants from wastewater: A review. J Environ Manage 2021, 285, 112-149, https://doi.org/10.1016/j.jenvman.2021.112149.

87. Subedi, B.; Lee, S.; Moon, H-B.; Kannan, K. Emission of artificial sweeteners, select pharmaceuticals, and personal care products through sewage sludge from wastewater treatment plants in Korea. Environ Int 2014, 68, 33-40, https://doi.org/10.1016/j.envint.2014.03.006.

88. Ding, Y.; Zhang, W.; Gu, C.; Xagoraraki, I.; Li, H. Determination of pharmaceuticals in biosolids using accelerated solvent extraction and liquid chromatography/tandem mass spectrometry. J Chromatogr A 2011, 1218, 10-16, https://doi.org/10.1016/j.chroma.2010.10.112.

89. McAvoy, D.C.; Schatowitz, B.; Jacob, M.; Hauk, A.; Eckhoff, W.S. Measurement of triclosan in wastewater treatment systems. Environ Toxicol Chem 2002, 21, 1323-1329, http://dx.doi.org/10.1002/etc.5620210701.

90. Nieto, A.; Borrull, F.; Pocurull, E.; Marcé, R.M. Occurrence of pharmaceuticals and hormones in sewage sludge. Environ Toxicol Chem 2010, 29, 1484-1489, https://doi.org/10.1002/etc.188.

91. Mohan, D.; Rajput, S.; Singh, V.K.; Steele, P.H.; Pittman, C.U. Modeling and evaluation of chromium remediation from water using low cost bio-char, a green adsorbent. J Hazard Mater 2011, 188, 319-333, https://doi.org/10.1016/j.jhazmat.2011.01.127.

92. Li, Z.; Tang, Q.; Katsumi, T.; Tang, X.; Inui, T.; Imaizumi, S. Leaf char: an alternative adsorbent for Cr(III). Desalination 2010, 264, 70-77, https://doi.org/10.1016/J.DESAL.2010.07.006.

93. Xu, R.K.; Xiao, S.C.; Yuan, J.H.; Zhao, A.Z. Adsorption of methyl violet from aqueous solutions by the biochars derived from crop residues. Bioresour Technol 2011, 102, 10293-10298, https://doi.org/10.1016/j.biortech.2011.08.089.

94. Varjani, S.; Joshi, R.; Srivastava, V.K.; Ngo, H.H.; Guo, W. Treatment of wastewater from petroleum industry: current practices and perspectives. Environ Sci Pollut Res Int 2020, 27, 27172-27180, https://doi.org/10.1007/s11356-019-04725-X.

95. Liu, G.; Zheng, H.; Jiang, Z.; Zhao, J.; Wang, Z.; Pan, B.; Xing, B. Formation and physicochemical characteristics of nano biochar: insight into chemical and colloidal stability. Environ Sci Technol 2018, 52, 10369-10379, https://doi.org/10.1021/acs.est.8b01481.

96. Lu, L.; Chen, B.L. Enhanced bisphenol a removal from stormwater in biochar amended biofilters: combined with batch sorption and fixed-bed column studies. Environ Pollut 2018, 243, 1539-1549, https://doi.org/10.1016/j.envpol.2018.09.097.

97. Lawal, A.A.; Hassan, M.A.; Ahmad Farid, M.A.; Yasim-Anuar, T.A.T.; Mohd Yusoff, M.Z.; Zakaria, M.R.; Roslan, A.M.; Mokhtar, M.N.; Shirai, Y. One-step steam pyrolysis for the production of mesoporous biochar from oil palm frond to effectively remove phenol in facultatively treated palm oil mill effluent. Environ. Technol. Innov. 2020, 18, https://doi.org/10.1016/j.eti.2020.100730.

98. Tong, M.; Li, T.; Li, M.; He, L.; Ma, Z. Cotransport and deposition of biochar with different sized-plastic particles in saturated porous media. Sci. Total Environ. 2020, 713, https://doi.org/10.1016/j.scitotenv.2019.136387.

99. Iqbal, J.; Shah, N.S.; Sayed, M.; Niazi, N.K.; Imran, M.; Khan, J.A.; Khan, Z.U.H.; Hussien, A.G.S.; Polychronopoulou, K.; Howari, F. Nano-zerovalent manganese/biochar composite for the adsorptive and oxidative removal of Congo-red dye from aqueous solutions. J. Hazard. Mater. 2021, 403, https://doi.org/10.1016/j.jhazmat.2020.123854.

100.Liang, G.; Yang, Z.; Wang, Z.; Cai, X.; Zhang, X.; Xie, X. Relying on the non-radical pathways for selective degradation organic pollutants in $\mathrm{Fe}$ and $\mathrm{Cu}$ co-doped biochar/peroxymonosulfate system: The roles of $\mathrm{Cu}$, Fe, defect sites and ketonic group. Sep. Purif. Technol. 2021, 279, https://doi.org/10.1016/j.seppur.2021.119697.

101. Mahmud, K.N.; Wen, T.H.; Zakaria, Z.A. Activated carbon and biochar from pineapple waste biomass for the removal of methylene blue. Environ. Toxicol. Manage. 2021, 1, 30-36, https://doi.org/10.33086/etm.v1i1.2036.

102.Wang, J.; Shi, L.; Zhai, L.; Zhang, H.; Wang, S.; Zou, J.; Shen, Z.; Lian, C.; Chen, Y. Analysis of the longterm effectiveness of biochar immobilization remediation on heavy metal contaminated soil and the potential 
environmental factors weakening the remediation effect: A review. Ecotoxicol. Environ. Saf. 2021, 207, https://doi.org/10.1016/j.ecoenv.2020.111261.

103.Gautam, R.K.; Goswami, M.; Mishra, R.K.; Chaturvedi, P.; Awashthi, M.K.; Singh, R.S.; Giri, B.S.; Pandey, A. Biochar for remediation of agrochemicals and synthetic organic dyes from environmental samples: A review. Chemosphere 2021, 272, https://doi.org/10.1016/j.chemosphere.2021.129917.

104.Wiedemeier, D.B.; Abiven, S.; Hockaday, W.C.; Keiluweit, M.; Kleber, M.; Masiello, C.A.; McBeath, A.V.; Nico, P.S.; Pyle, L.A.; Schneider, M.P.W.; Smernik, R.J.; Wiesenberg, G.L.B.; Schmidt, M.W.I. Aromaticity and degree of aromatic condensation of char. Org Geochem 2014, 78, 135-143, https://doi.org/10.1016/j.orggeochem.2014.10.002.

105. Ganie, Z.A.; Khandelwal, N.; Tiwari, E.; Singh, N.; Darbha, G.K. Biochar-facilitated remediation of nanoplastic contaminated water: Effect of pyrolysis temperature induced surface modifications. J. Hazard. Mater. 2021, 417, https://doi.org/10.1016/j.jhazmat.2021.126096.

106. Siddiq, M.O.; Tawabini, B.; Kirmizakis, P.; Kalderis, D.; Ntarlagiannis, D.; Soupios, P. Combining geophysics and material science for environmental remediation: Real-time monitoring of Fe-biochar arsenic wastewater treatment. Chemosphere 2021, 284, https://doi.org/10.1016/j.chemosphere.2021.131390.

107. Bianco, F.; Race, M.; Papirio, S.; Oleszczuk, P.; Esposito, G. The addition of biochar as a sustainable strategy for the remediation of PAH-contaminated sediments. Chemosphere 2021, 263, https://doi.org/10.1016/j.chemosphere.2020.128274.

108. Liang, L.; Xi, F.; Tan, W.; Meng, X.; Hu, B.; Wang, X. Review of organic and inorganic pollutants removal by biochar and biochar-based composites. Biochar 2021, 3, 255-281, https://doi.org/10.1007/s42773-02100101-6.

109. Xu, C.; Tan, X.; Zhao, J.; Cao, J.; Ren, M.; Xiao, Y.; Lin, A. Optimization of biochar production based on environmental risk and remediation performance: Take kitchen waste for example. J. Hazard. Mater. 2021, 416, https://doi.org/10.1016/j.jhazmat.2021.125785.

110. Yang, Y.; Ye, S.; Zhang, C.; Zeng, G.; Tan, X.; Song, B.; Zhang, P.; Yang, H.; Li, M.; Chen, Q. Application of biochar for the remediation of polluted sediments. J. Hazard. Mater. 2021, 404, https://doi.org/10.1016/j.jhazmat.2020.124052. 